\title{
TRŽIŠNA PRIHVATLJIVOST GRAĐEVINSKOG MATERIJALA S MALIM UDJELOM UGLJIKA - DIO I: MATERIJALI I MOGUĆNOSTI SMANJENJA UTJECAJA NA OKOLIS̆
}

\author{
Tihomir Dokšanović \\ Sveučilište Josipa Jurja Strossmayera u Osijeku, Građevinski fakultet Osijek, mag.ing.aedif. \\ Mario Farkaš \\ Artifex d.o.o. Čepin, mag.ing.aedif. \\ Nataša Njegovanović \\ Sveučilište u Zagrebu, Studij dizajna pri Arhitektonskom fakultetu, student
}

\begin{abstract}
Sažetak: Materijali s malim udjelom ugljika danas su gotovo jednako prihvaćeni kao njihove konvencionalne inačice, ali njihova zastupljenost na tržištu nije značajna, unatoč očitoj dobrobiti po pitanju zaštite okoliša i time ljudskog zdravlja. U okviru održive gradnje pokušava se korisniku prikazati kako umjetno stvoreni, izgrađeni okoliš ima skrivene utjecaje te da učinci proizvodnje, transporta, ugradnje, korištenja i odlaganja materijala mogu biti značajni za njega i prirodu. Prema nekoliko metoda procjene utjecaja materijala na okoliš i prema zastupljenosti u graditeljskoj praksi, beton, asfalt i najčešće korišteni metali, čelik i aluminij, predstavljaju područje na koje treba djelovati kako bi se trenutačno stanje poboljšalo. Kroz projektiranje, izmjene sastava i intervencije na proizvodni proces, nužno je smanjiti njihov utjecaj na okolišs, a osim toga potrebno je bitnim značajkama novih inačica tih materijala, u ekonomskom i građevinskom kontekstu, opravdavati potreban veći udio u prodaji građevinskog materijala.
\end{abstract}

Ključne riječi: održiva gradnja, tržište, asfalt, čelik, beton, okoliš

\section{MARKET ACCEPTANCE OF LOW-CARBON BUILDING MATERIALS - PART I: MATERIALS AND POSSIBILITIES FOR REDUCING THE ENVIRONMENTAL IMPACT}

\begin{abstract}
Construction materials with low-carbon content are now practically equally accepted as their conventional counterparts, but their presence in the market is not significant, despite obvious benefits in terms of environmental protection and thus human health. Through the concept of sustainable building the user is being shown how artificially created, built environment, has hidden influences and that the impacts of production, transportation, installation, use and disposal of construction materials can be considerable to him and nature. In accordance with several methods of assessment of construction materials environmental impact, and by use in building practice, concrete, asphalt, and most commonly used metals, steel and aluminum, are the target of interest when it comes to the improvement of the current situation. Through the design, composition changes and interventions in the production process it is necessary to reduce their impact on the environment, and in addition, it is necessary to show that the important characteristics of the new variants of these materials, in construction and economic context, justify a needed larger share in the sales of construction materials.
\end{abstract}

Key words: sustainable building, market, asphalt, steel, concrete, environment 


\section{Uvod}

Tržište je, prema najkraćoj definiciji, mjesto gdje se susreću ponuda i potražnja, a kao sastavnica ekonomije podliježe njezinim zakonima i procesima. Ekonomija, kao vodilja tržišta, predstavlja ukupnost čovjekove djelatnosti na održanju i unaprjeđivanju njegove materijalne egzistencije, a često se može reći i kako je ekonomija gospodarstvo, u najširem smislu, odnosno njegovo vođenje i racionalno upravljanje. Osim toga, ekonomija je razumna uporaba novca ili kakva drugoga sredstva radi postizanja najveće koristi uz najmanji utrošak materijala i rada, te ukupnost odnosa privređivanja i proizvodnje u društvu. S druge strane, naizgled nasuprot je održivost, a u samoj srži i održiva gradnja, koja predstavlja sposobnost održavanja ravnoteže određenih procesa ili stanja u nekom sustavu.

Ako se sve navedene definicije ekonomije pažljivije promotre, moguće je primijetiti kako sadrže pojmove kao što su održanje, racionalnost i razumnost, a zar je nešto što šteti ekosustavu moguće povezati s tim pojmovima? Zar je razumno uništavati izvor privređivanja? Lako je doći do zaključka kako je održiva gradnja, u suštini, istinska primjena ekonomije. Drugim riječima, održiva gradnja i kao nužnost u njoj materijali s malom razinom ugljika predstavljaju jedino sredstvo koje nudi stvarnu ravnotežu između ponude i potražnje na dugoročnoj osnovi. Takvi zeleni materijali trebali bi prednjačiti na tržištu koje je proizvod ekonomskog sustava.

Stanje na današnjem tržištu ne odgovara ovom logički jasnom stanju. lako se postupnim ekološkim osvještavanjem postiglo da se danas ne postavlja pitanje prihvatljivosti građevinskih materijala s malim udjelom ugljika, postavlja se pitanje kako omogućiti poboljšanje položaja takvih materijala na tržištu te kako potaknuti veću potražnju za istima.

Uzrok prilika kojih smo svjedoci, a to je navedena nedovoljna zastupljenost zelenih materijala na tržištu, funkcija je velikog broja varijabli od kojih prednjače nedostatna informiranost i obrazovanje društva 0 posljedicama koje donosi neuravnoteženo stanje tržišta i time prirode. Dakle, prvi korak ka poboljšanju stanja je prikaz mogućnosti promjene te iznošenje prednosti koje bi takva promjena donijela krajnjem korisniku i industriji koja bi promjenu prihvatila kako bi zadovoljila potrebe korisnika.

\section{Održiva gradnja}

Kao jedna od vodilja na putu ka održivosti jest pokret „održiva gradnja“ koji se u stvarnosti prikazuje kroz složenu mrežu projektiranja, proizvodnje, raspodjele, gradnje, korištenja i odlaganja, a hvata u koštac s pitanjima budućnosti kroz stalnu promjenu i napredak. lako „održiva gradnja“ predstavlja određenu ideju, daleko je od nečega što lako odaje svoju svrhu - predstavlja nepojmljivu artikulaciju složenosti, prvenstveno zbog široke lepeze zainteresiranih struka i broja područja djelokruga. Veliki broj projektanata, arhitekata i dizajnera teško si poima dalekosežnost utjecaja materijala na okoliš i ljudsko zdravlje. Nakon razotkrivanja svega što održiva gradnja sa sobom nosi, potrebno je ostvariti sve potrebne društveno-kulturalne-ekonomske-tehnološke preduvjete da ona u potpunosti zaživi. Treba imati na umu kako ona možda i nije u potpunosti moguća u monetarnom sustavu kojim upravlja profit koji diktira ono što je vrijedno, a što nije. Upravo zato, do prelaska na neke druge sustave i skupove društvenih vrijednosti, treba kroz prizmu trenutačnih sustava naći rješenje problema nedovoljne zastupljenosti ekološki prihvatljivih materijala i proizvodnih procesa.

Mogući postupci prihvaćanja zelenih materijala na tržištu su informiranje, suradnja, obrazovanje, sklapanje partnerstva, certificiranje, znanstveni skupovi, seminari, radionice, adresari, baze podataka, primjeri iz prakse i kampanje. Navedenim postupcima treba ljude dodatno ekološki osvijestiti, a time će zeleni materijali postati društveno prihvatljiviji i kulturno privlačniji. lako na globalnoj razini postoji uzlazni tijek ove „zelene“ borbe, počinjući od sporazuma protiv onečišćavanja, intervencija u proizvodne procese koji uzrokuju onečišćenje, do redizajna proizvoda i usluga koji čine takve procese nužnim, potrebno je uložiti značajna sredstva kako bi ovaj trend zadržao povoljnu putanju. Činjenice koje idu na ruku održivoj „industriji“ su ekonomska kriza, koja potiče promjene u razmišljanju i intrigira ljude za nešto suprotno od trenutačnog, zatim povoljni psihološki učinci zelenih materijala na korisnike, bolji imidž zelenih tvrtki koje su percipirane kao društveno odgovorne, financijske olakšice za certificirane zgrade i materijale, ponegdje i participacija države pri kupnji zelenih proizvoda, te još mnogo toga. Naravno, treba naglasiti kako jedino rješenje problema nije nužno u novom, zelenom materijalu, nego u konvencionalnim, iskušanim i provjerenim materijalima korištenim na zeleni način. Treba pretpostaviti da 
konvencionalni materijali mogu biti eventualno zamijenjeni svojim zelenim inačicama, ali za ovo vrijeme, inženjeri moraju poduzeti korake kako bi promijenili konvencionalne materijale na takve načine koji bi umanjili njihov utjecaj na okoliš i ljudsko zdravlje. Na primjer, u budućnosti se možda pronađe materijal koji se ponaša bolje od asfalta, ima manju cijenu i široko je prihvaćen u cestovnoj industriji te je bolji u smislu utjecaja na okoliš i ljudsko zdravlje, ali u međuvremenu inženjeri moraju poduzeti korake kako bi promijenili asfalt na takav način da se umanje njegovi negativni učinci, recimo u vidu korištenja recikliranih agregata u proizvodnji.

\subsection{Zašto zgrade i materijali?}

Moguće je postaviti pitanje zašto je zgradarstvo tako veliki dio koncepta održivosti i zašto sada, ako svijet sasvim dobro funkcionira prema trenutačnim sustavima? Naime, zgrade su kroz proizvodnju za izradu potrebnih materijala, izvođenje, uporabu i odlaganje otpada nakon rušenja, odgovorne za preko 40\% [1] emisija ugljikova dioksida na globalnoj razini. Dakle, zgrade su jedan od glavnih krivaca povezanih s fenomenom globalnog zatopljenja. Sjedinjene Američke Države, Europa, Kanada i Japan proizvode većinski udio stakleničkih emisija u ovom trenutku, no ova situacija će se značajno mijenjati u bližoj budućnosti. Predviđeni brzi porast emisija ugljikovog dioksida u Kini, Indiji i ostatku Azije, Brazilu i Rusiji, daje imperativ svijetu da sudjeluje u smanjenju „stakleničkog otiska" urbane civilizacije tijekom sljedećih 30 godina. Globalna povećanja temperature su neizbježna, sa značajnim posljedicama za sve. Situacija je negativna i treba djelovati danas, prvenstveno kako bi se izbjegle moguće velike klimatske promjene i ozbiljni ekonomski i zdravstveni prevrati tijekom sljedećih 30 do 50 godina.

$\mathrm{Na}$ pitanje zašto materijali, moguće je odgovoriti također činjenicama. Naš umjetno stvoreni, izgrađeni okoliš, ima skrivene utjecaje na ljudsko zdravlje i prirodni okoliš. Učinci proizvodnje, transporta, ugradnje, korištenja i odlaganja materijala mogu biti značajni, a opet često nevidljivi za korisnika. Pri korištenju svakog od materijala i proizvoda u umjetnom okolišu, aktivira se široka i složena mreža utjecaja na prirodu i ljudsko zdravlje koja seže daleko izvan gradilišta - materijali i proizvodi koje koristimo mogu biti proizvedeni stotinama pa i tisućama kilometara dalje, što štetne posljedice na ekosustave na mjestu crpljenja i proizvodnje čini nevidljivima. Transport kroz sve faze materijala zahtijeva gorivo i doprinosi onečišćenju atmosfere. Odlaganje proizvodnog otpada i iskorištenog građevinskog materijala utječe na još jednu okolišnu sredinu. Dakle, utjecaj gradnje je često nevidljiv krajnjem korisniku - primjerice, uništavanje močvara na mjestu gradnje može biti jasno i razumljivo prikazano, ali teško je prikazati učinke globalnog zagrijavanja koji za uzrok imaju ispuštanje $\mathrm{CO}_{2}$ pri proizvodnji betona, ili uništavanje prašuma na drugom kraju svijeta kako bi se vadio boksit za proizvodnju aluminija.

\section{Materijali i mogućnosti smanjenja utjecaja na okoliš}

Tijekom prošlih desetljeća ustanovljeni su mnogi načini procjene utjecaja materijala na okoliš, razvijeni unutar određenih programa certificiranja ili kao zasebna istraživanja. Pomoću takvih procjena moguće je uvidjeti koliki je ukupni utjecaj materijala na okoliš, što se naziva ugrađena energija (embodied energy), te kako određeni materijal utječe na prirodu kroz faze, od samog iskopa pa do odlaganja, preko takozvane procjene životnog ciklusa (life-cycle assessment) - ona daje mogućnost da za svaki materijal možemo odrediti problematične faze. lako se količina ispuštenog $\mathrm{CO}_{2}$ određenog materijala često podudara s ugrađenom energijom materijala, to nije uvijek slučaj, tako da je razvijena i metoda procjene ukupnih emisija $\mathrm{CO}_{2}$ u životnom ciklusu materijala pod nazivom ugrađeni ugljik (embodied carbon).

Većina materijala ima linearni životni ciklus, što znači da se materijali kreću kroz ciklus samo jednom, od crpljenja do odlaganja; neki su djelomično kružni u pogledu ponovnog korištenja proizvoda, ponovne proizvodnje pojedinih komponenti ili reciklaže materijala. Idealni životni ciklus materijala bio bi zatvorena petlja, kružni tok gdje je otpad jednog procesa ili proizvoda „hrana" za drugi (Slika 1). 


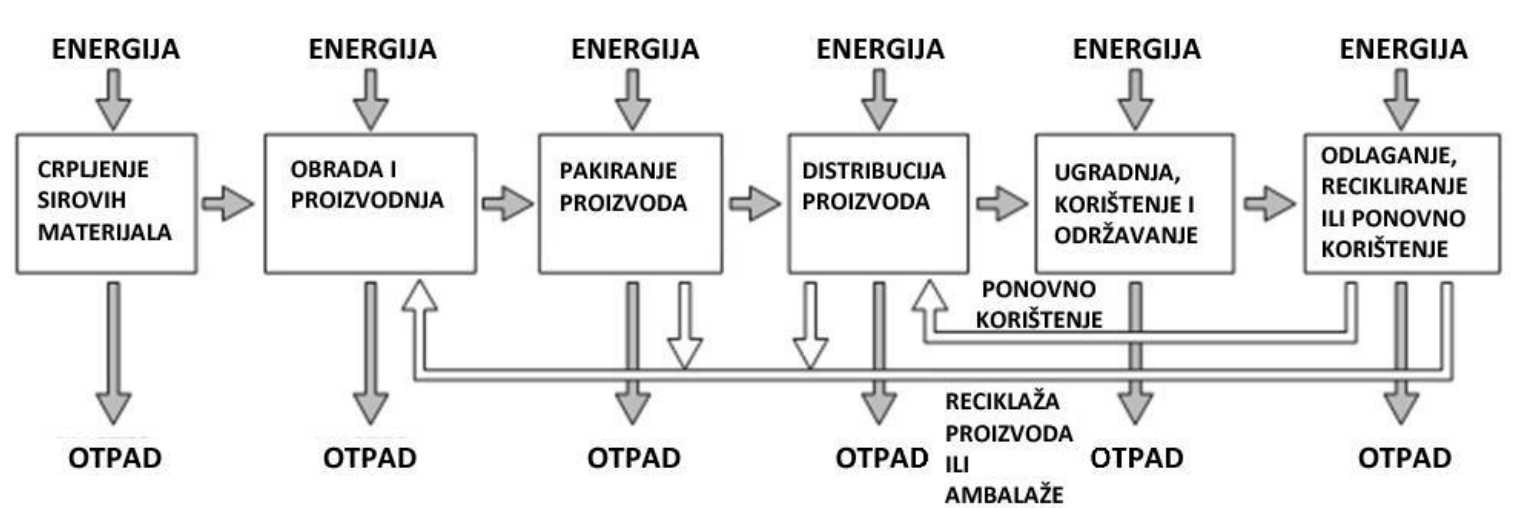

\section{Slika 1 - Uobičajene faze životnog ciklusa materijala ili proizvoda, s prikazanim energetskim ulazima i otpadnim izlazima [2]}

Ulaskom u 21. stoljeće pojačano je djelovanje na području održive gradnje tako da su istraživanjima [2-4] utvrđene količine ugrađene energije i ugljika danas najviše upotrebljavanih građevinskih materijala i njihovih zelenih inačica (Slika 2). Konvencionalni materijali su učinjeni ekološki povoljnijima zamjenom njihovih sastavnica ili promjenama u procesu proizvodnje, ovisno o tome koja je faza životnog ciklusa ključna za negativne učinke, tako da im je uvelike umanjena ugrađena energija i ugljik. Takvi materijali, iako uz očite prednosti, tek traže potvrdu tržišta kroz veći udjel u prodaji. Upravo za najviše istražene konvencionalne materijale najprimjetniji je trend pronalaska alternativnih rješenja - beton, asfalt i čelik.

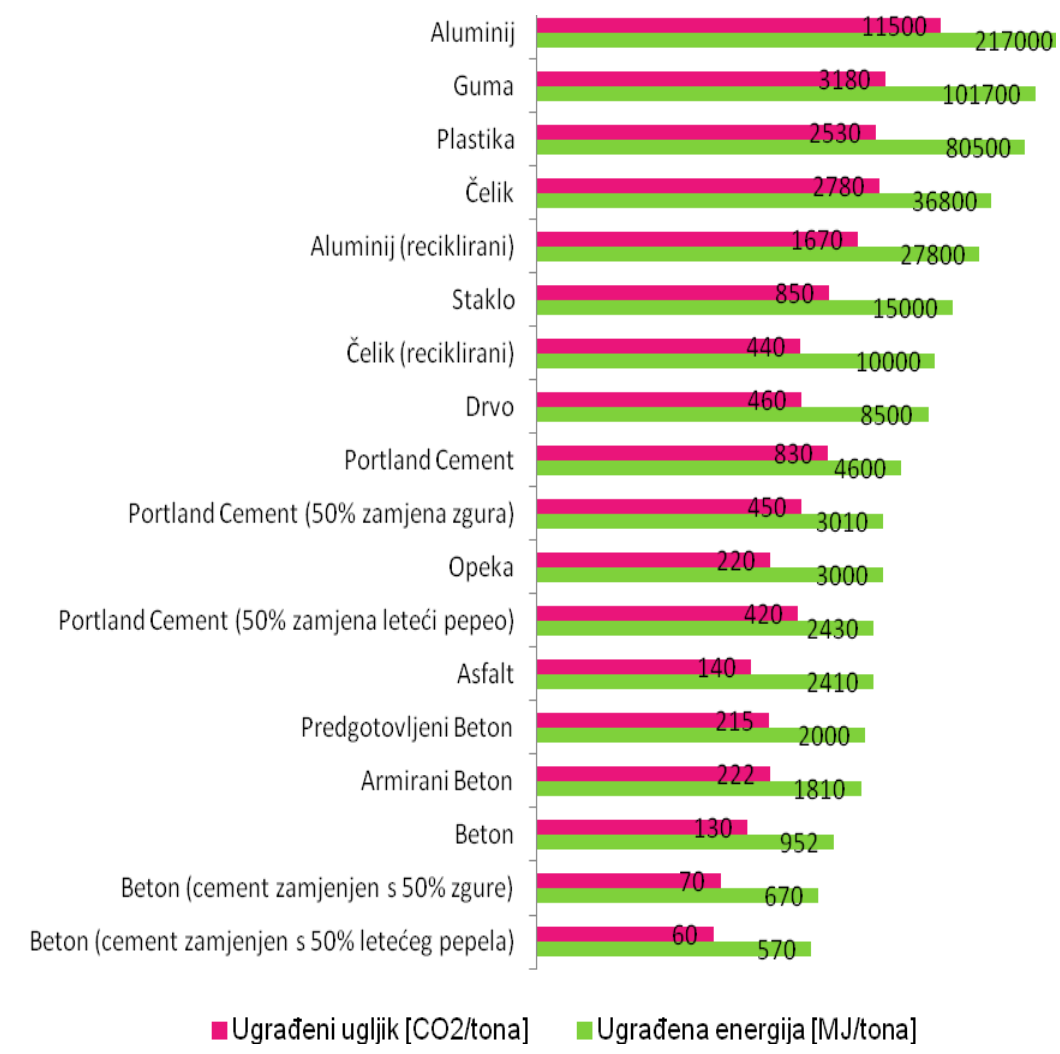

Slika 2 - Ugrađena energija (EE) i ugrađeni ugljik (EC) najčešćih građevinskih materijala [2]

\subsection{Beton}


Beton kao gotov proizvod je ekološki čist materijal, a zahvaljujući svojim oblikovnim svojstvima betonske konstrukcije se mogu dobro uklopiti u okolinu, kako urbanu tako i ruralnu. Međutim, proizvodnja betona, odnosno njegovih sastavnica, ima veliki utjecaj na okoliš. Najčešći sastav u volumenu betona čine agregat (krupni i sitni), cement (uobičajeno portland), voda i zrak, uz primjese dodataka koji utječu na određena svojstva (Slika 3).

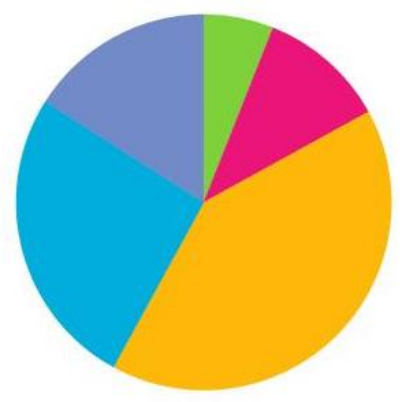

$\operatorname{zrak}(6 \%)$

- Portland cement (11\%) $\rightarrow$ 1,6 mlrd t/god.

agregat (krupni) (41\%)

n agregat (sitni) (26\%) $\quad$ 10-11 mlrd t/god.

voda $(16 \%) \longrightarrow 1 \mathrm{mlrd}$ t/god.

\section{Slika 3 - Volumni udio pojedinih sastojaka u betonu i njihova godišnja potrošnja u svijetu [5]}

Pri proizvodnji betona godišnje se u svijetu upotrijebi 10-11 [2] milijardi tona agregata, a iskop, obrada i transport tako velikih količina agregata zahtijevaju goleme količine energije i utječu na prirodnu ravnotežu. Betonska industrija, pored navedenog, koristi i velike količine svježe vode, jednu [2] milijardu tona godišnje. lako su ove brojke zastrašujuće velike, najveći udio u negativnom učinku betona na prirodni okoliš zauzima proizvodnja portland cementa. Naime, za svaku proizvedenu tonu cementa potrebno je potrošiti 1,5 tonu vapnenca, uz fosilna goriva kao energiju u proizvodnji. Na godišnjoj bazi proizvede se 1,6 milijardi tona cementa, što je odgovorno za 7\% [6] ukupnih emisija $\mathrm{CO}_{2}$ u atmosferu. Tabela 1 predstavlja SWOT (Strengths, Weaknesses, Opportunities and Threats) analizu stanja cementne industrije u današnjoj borbi protiv klimatskih promjena te kao takva najbolje ističe bitno za napredak ka uravnoteženoj, održivoj budućnosti.

\section{Tabela 1 - SWOT analiza stanja cementne industrije po pitanju klimatskih promjena [7]}

\begin{tabular}{|c|c|}
\hline Snage & Prilike \\
\hline $\begin{array}{l}\text { Pojedini proizvođači smanjili su količine emisije } \mathrm{CO}_{2} \text { po } \\
\text { toni proizvoda } \\
\text { Deset najvećih proizvođača cementa, uz vanjske } \\
\text { suradnike, razvilo je standardizirani protokol praćenja } \\
\text { emisija } \mathrm{CO}_{2}\end{array}$ & $\begin{array}{l}\text { Poboljšanje energetske učinkovitosti } \\
\text { Uporaba alternativnih sirovinskih materijala } \\
\text { Uporaba alternativnih, nisko-ugljičnih goriva } \\
\text { Zasluge za smanjenje štetnih emisija } \\
\text { Smanjenje troškova kroz sustav trgovanja emisijama } \mathrm{CO}_{2}{ }^{1}\end{array}$ \\
\hline Slabosti & Prijetnje \\
\hline $\begin{array}{l}\text { Velika ovisnost o fosilnoj energiji } \\
\text { Cement na osnovi vapnenca je osnova proizvodnje } \\
\text { Nedovoljna usredotočenost na potrebna značajna } \\
\text { smanjenja emisije } \mathrm{CO}_{2} \\
\text { Isprekidani angažman bez jasnog dugoročnog plana u } \\
\text { aktivnostima usmjerenim na klimatske regulative } \\
\text { Nedovoljna ulaganja u istraživanja koja bi omogućila } \\
\text { jeftina smanjenja } \mathrm{CO}_{2} \text { emisija }\end{array}$ & $\begin{array}{l}\text { Velika financijska opterećenja zbog onečišćavanja } \\
\text { Mogućnost nametnutih tehnoloških kontrola } \\
\text { Rano umirovljenje tvornica i opreme } \\
\text { Mogućnost da cementna industrija bude zanemarena pri } \\
\text { stvaranju klimatskih regulativa, te da se takvim } \\
\text { regulativama dovede u nepovoljan položaj uz bok velikih } \\
\text { onečišćivača } \\
\text { Gubitak udjela na tržištu zbog konkurentnih materijala koji } \\
\text { su ekološki povoljniji }\end{array}$ \\
\hline
\end{tabular}

1 (EU Emissions Trading System (EU ETS) i slični sustavi predstavljaju načine suzbijanja klimatskih promjena preko tzv. „cap and trade“ principa - više na http://ec.europa.eu/clima/policies/brief/eu/index_en.htm)

\subsubsection{Učinkovito korištenje betona}


Jedan od načina učinkovitijeg korištenja betona jest gradnja trajnijih građevina. Veliki broj betonskih konstrukcija i kolnika izloženih atmosferilijama nije građen tako da bude u stanju trajati 30-40 godina svog projektnog životnog vijeka - u prosjeku traju oko polovine toga vremena [8]. Prijevremeni gubitak uvjeta uporabivosti konstrukcija za posljedicu ima korištenje velikih količina resursa za izgradnju novih konstrukcija koje in moraju zamijeniti. Smanjena trajnost može biti posljedica mnogo čimbenika, bilo neodgovarajućeg sastava betona, neodgovarajućeg postupka betoniranja i njege, ili prekomjernog korištenja dodataka [8]. Mješavine betona prilagođene određenoj uporabi; korištenje pucolanskih cemenata ili cementnih industrijskih nusprodukata, kao što su leteći pepeo, silicijska prašina ili zgura visokih peći; ili korištenje betona visokih performansi (HPC - high performance concrete) - mogu produžiti životni vijek konstrukcija.

Razvoj i povećano korištenje betona visokih performansi mogu umanjiti količine cementa, vode i agregata korištenih u betonu te omogućiti gradnju trajnijih konstrukcija. HPC je beton svojstven po malom omjeru vode i cementa (vodo-cementni omjer) u mješavini, što se postiže uporabom super plastifikatora i zamjenom dijela cementa pucolanskim dodatcima kako bi se poboljšala obradivost u svježem stanju. Ovakav beton je ekonomičan materijal zato što konstrukcije u kojima se koristi mogu biti manje i vitkije (tlačne čvrstoće takvog betona kreću se do $100 \mathrm{~N} / \mathrm{mm}^{2}$ [9]), a tada se koristi manje betona i betonskog čelika, a ljudski rad sveden je na najmanju mjeru (armirači, tesari, trajanje betoniranja). Osim navedenih prednosti, ovakvi betoni imaju mali koeficijent poroznosti, što ih čini otpornijim na smrzavanje i odmrzavanje, prodiranje sulfata i klorida i ostala kemijska djelovanja. Procijenjeno je da betoni visokih performansi imaju životni ciklus dva do tri [2] puta dulji od uobičajenog betona.

Osim obraćanja više pozornosti trajnosti konstrukcija, moguće je utjecati na smanjenje učinka betona na okoliš kroz projektiranje. Primjerice, u zemljama gdje prevladavaju hladni klimatski uvjeti, umjesto gradnje uobičajenih konzolnih potpornih zidova, koji zahtijevaju značajno temeljenje kako bi se ukopali ispod dubine smrzavanja tla, prakticira se uporaba modularnih sustava potpornih zidova na pješčanoj podlozi, što značajno umanjuje potrošnju betona [10]. Prilikom temeljenja uobičajenih zgrada, uporaba dubokog temeljenja (pomoću pilota) omogućuje značajne uštede betona u usporedbi s plitkim temeljenjem, pritom zadržavajući istu nosivost $i$ pouzdanost. Još jedan od jednostavnih primjera kako umanjiti negativne ekološke utjecaje pri gradnji, jest korištenje oblika betonskih presjeka koji omogućuju uporabu recikliranih materijala kao oplate (primjer sonotube ${ }^{\circledR}$ [11], kružna oplata od recikliranog kartona) - ovime se umanjuje utjecaj na okoliš pri uporabi čeličnih ili drvenih oplata (Slika 4). Ove mjere ne samo da jamče smanjenje utjecaja na okoliš, nego često i uštedu novca.
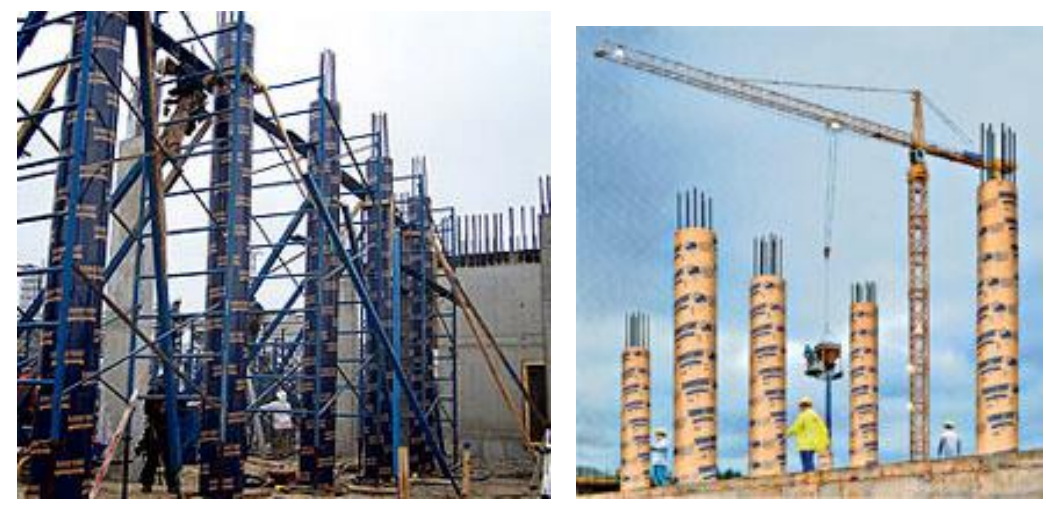

Slika 4 - Primjer korištenja recikliranog kartona u obliku oplate [11]

\subsubsection{Umanjenje utjecaja portland cementa na okoliš}

S obzirom na to da je najveći negativni utjecaj betona na okoliš posljedica proizvodnje portland cementa, smanjenje njegove uporabe je jedan od najvažnijih koraka prema „zelenijem“ betonu. Strategije umanjenja utjecaja cementa na okoliš uključuju smanjenje količine cementa u betonskoj mješavini i zamjenu dijela portland cementa u betonskoj mješavini inačicama, pucolanskim industrijskim nusproduktima.

Korištenje manjih količina cementa u betonskoj mješavini bilo bi lako moguće kada bi se trenutačna odredba 0 nužnosti postizanja pune (propisane) čvrstoće betona nakon 28 dana, promijenila na potrebnih 56 
dana. Istraživanjima [2] je prikazano da bi ovakav pristup, osim navedene prednosti, imao za posljedicu trajnije konstrukcije. Takva odredba bi omogućila i veće postotke zamjene portland cementa cementnim industrijskim nusproduktima u betonskoj mješavini, jer je jedna od osnovnih prepreka zamjene većih postotaka portland cementa sporiji prirast čvrstoća. Osim toga, povoljne učinke dodataka silikatne prašine i pucolana moguće je postići samo kroz pravilnu njegu uz duže trajanje nego što se minimalno zahtijeva propisima.

Smanjenje uporabe portland cementa u betonskoj mješavini najlakše je ostvarivo njegovom zamjenom ostalim pucolanskim ili hidrauličnim materijalima. U 2000. godini „Portland Cement Association“ objavila je kako su alternativni cementni materijali djelomično zamijenili portland cement (ili su korišteni kao dodatak) u preko $60 \%$ suvremenih betonskih mješavina. Danas je ovaj postotak vjerojatno i veći zbog toga što je korištenje alternativnih cementnih materijala doživjelo veće prihvaćanje tržišta.

Najčešće zamjene portland cementa su industrijski nusprodukti, bilo kao zasebne zamjene ili kombinacije u betonskoj mješavini. Industrijski nusprodukti koji mogu poslužiti kao zamjena portland cementa su leteći pepeo (razreda C i F), zgura visokih peći i silikatna prašina. Uz industrijske nusprodukte postoje i zamjene u vidu prirodnih pucolana kao što su kaolinske gline, metakaolin i sagorjeli škriljac [12]. Procijenjeno je kako bi smanjenje portland cementa u betonskoj mješavini od samo $30 \%$ [8] prekinulo porast emisija $\mathrm{CO}_{2}$ za koje je odgovorno kontinuirano povećanje proizvodnje betona, a danas je moguće smanjenje udjela portland cementa i do $100 \%$. Zamjenom $50 \%$ cementa zgurom iz visokih peći, ugrađena energija betona smanjuje se za $34 \%$, a ugrađeni ugljik za $46 \%$ (Slika 2).

Svaka od mogućih djelomičnih ili potpunih zamjena portland cementa u betonskoj mješavini ima svoje prednosti i nedostatke, od kojih se neke odnose na svojstva betona, bilo u svježem ili očvrsnulom stanju - takvi utjecaji su ukratko prikazani u Tabela $2 \mathrm{i}$ Tabela 3.

Tabela 2 - Utjecaj cementnih zamjena na svojstva svježeg betona [13]

\begin{tabular}{|c|c|c|c|c|c|}
\hline & \multicolumn{2}{|c|}{ Leteći pepeo } & \multirow{2}{*}{$\begin{array}{c}\text { Granulirana } \\
\text { zgura visoke } \\
\text { peći }\end{array}$} & \multirow{2}{*}{$\begin{array}{l}\text { Silikatna } \\
\text { prašina }\end{array}$} & \multirow{2}{*}{ Metakaolin } \\
\hline & Razred F & Razred C & & & \\
\hline Udio vode & $\begin{array}{l}\text { značajno } \\
\text { smanjen }\end{array}$ & $\begin{array}{l}\text { značajno } \\
\text { smanjen }\end{array}$ & smanjen & $\begin{array}{l}\text { značajno } \\
\text { povećan }\end{array}$ & povećan \\
\hline Obradivost & povećana & povećana & povećana & $\begin{array}{l}\text { značajno } \\
\text { smanjena }\end{array}$ & smanjena \\
\hline $\begin{array}{l}\text { Izdvajanje vode i } \\
\text { segregacija }\end{array}$ & smanjeno & smanjeno & učinak varira & $\begin{array}{l}\text { značajno } \\
\text { smanjeno }\end{array}$ & smanjeno \\
\hline Udio zraka & $\begin{array}{l}\text { značajno } \\
\text { smanjen }\end{array}$ & smanjen & smanjen & $\begin{array}{l}\text { značajno } \\
\text { smanjen }\end{array}$ & smanjen \\
\hline Toplina hidratacije & smanjena & učinak varira & smanjena & $\begin{array}{c}\text { nema značajne } \\
\text { promjene }\end{array}$ & smanjena \\
\hline Vrijeme vezanja & povećano & učinak varira & povećano & $\begin{array}{c}\text { nema značajne } \\
\text { promjene }\end{array}$ & $\begin{array}{c}\text { nema značajne } \\
\text { promjene }\end{array}$ \\
\hline Završna obrada & poboljšana & poboljšana & poboljšana & učinak varira & poboljšana \\
\hline Pumpabilnost & povećana & povećana & povećana & povećana & povećana \\
\hline $\begin{array}{l}\text { Plastično } \\
\text { skupljanje i } \\
\text { pucanje }\end{array}$ & $\begin{array}{l}\text { nema značajne } \\
\text { promjene }\end{array}$ & $\begin{array}{c}\text { nema značajne } \\
\text { promjene }\end{array}$ & $\begin{array}{l}\text { nema značajne } \\
\text { promjene }\end{array}$ & povećano & $\begin{array}{c}\text { nema značajne } \\
\text { promjene }\end{array}$ \\
\hline
\end{tabular}

Tabela 3 - Utjecaj cementnih zamjena na svojstva očvrsnulog betona [13] 


\begin{tabular}{lccccc}
\hline & \multicolumn{2}{c}{ Leteći pepeo } & $\begin{array}{c}\text { Granulirana } \\
\text { zgura visoke } \\
\text { peći }\end{array}$ & $\begin{array}{c}\text { Silikatna } \\
\text { prašina }\end{array}$ & Metakaolin \\
\cline { 2 - 4 } Rane čvrstoće & Razred F & Razred C & $\begin{array}{c}\text { značajno } \\
\text { povećane }\end{array}$ & $\begin{array}{c}\text { značajno } \\
\text { povećane }\end{array}$ \\
Dugotrajne čvrstoće & smanjene & $\begin{array}{c}\text { nema značajne } \\
\text { promjene }\end{array}$ & smanjene & značajno & $\begin{array}{c}\text { značajno } \\
\text { povećane }\end{array}$ \\
Propusnost & povećane & povećane & povećane & povećane & značajno \\
smanjena
\end{tabular}

\subsubsection{Zamjena prirodnih agregata recikliranima}

Zamjenjujući prirodne agregate u betonskoj mješavini recikliranima, moguće je ostvariti ekonomske, okolišne, pa čak i estetske dobrobiti. Osim što se takvim postupcima mogu umanjiti količine iskopa prirodnih agregata, moguće je umanjiti utjecaj koji na okoliš ima rudarska industrija, a i smanjiti popunjavanje odlagališta otpada. Svakako je bitno napomenuti kako reciklirani agregati mogu biti jeftiniji od prirodnih agregata, osobito ako su materijali za odlaganje, kao što su opeka ili beton, drobljeni na ili blizu gradilišta gdje se koriste u novom betonu. Beton se lako reciklira na samom gradilištu pomoću opreme koja ruši, prikuplja i zatim drobi stari materijal. Ovakva praksa može ukloniti troškove prijevoza otpada do odlagališta te troškove samog odlaganja. Sve ove koristi govore o tržišnom potencijalu recikliranih agregata, prvenstveno zbog očitih financijskih ušteda koje tržište najlakše prihvaća.

Uz navedene, reciklirani proizvodi koje je moguće koristiti kao krupni ili sitni agregat u betonskoj mješavini su drobljena zgura, crijep, staklo, granulirana plastika, otpadna staklo-plastika i mnogi drugi. lako je većina od navedenih recikliranih agregata provjerena u betonu, samo su drobljeni beton, zgura i staklo naišli na široku primjenu u građevinarstvu [10].

Ograničenje koje značajno koči rast uporabe recikliranih materijala kao agregata jest zahtjev za predvidivim i postojanim svojstvima konačnog proizvoda. Ako su vrsta i količina štetnih sastojaka u recikliranim materijalima nepoznati, svojstva betona u kojima su takvi materijali upotrijebljeni kao agregat nisu predvidiva i mogu izazvati nepredviđen štetan učinak na čvrstoću i trajnost betona [14]. Osim toga, problem korištenja sitnih frakcija je preveliko upijanje vode te manja specifična masa u odnosu na prirodni agregat, što može imati za posljedicu betone $s$ naglašenijim skupljanjem i puzanjem - ovo je moguće riješiti kombiniranjem prirodnog i recikliranog agregata, što je opet ekološki prihvatljivo. Mješavine treba prilagoditi kako bi odgovarale odstupanjima u svojstvima agregata, a i treba imati na umu da reciklirani agregati ne smiju sadržavati komponente koje mogu negativno reagirati kada su pomiješane s cementom.

\subsection{Asfalt}


Asfalt je mješavina mineralnih tvari, krupnih i sitnih agregata, i asfaltnog vezivna (obično bitumen) (Slika 5). Najčešća primjena asfalta je u cestogradnji, što je posljedica svojstava asfaltne mješavine kao što su fleksibilnost, vodonepropusnost, brzo nanošenje (nema potrebe za oplatom, armaturom i slično) te varijabilnost komponenti (vrsta i količina) koja omogućava proizvodnju asfalta koji ima različita svojstva, ovisno o potrebi. Najčešće se koriste vruće mješavine asfalta, što podrazumijeva da su svi sastojci zagrijani u tvornici asfalta do temperature od $120^{\circ} \mathrm{C}$ do $180^{\circ} \mathrm{C}$ (Slika 6), a nakon toga isporučeni na gradilište.

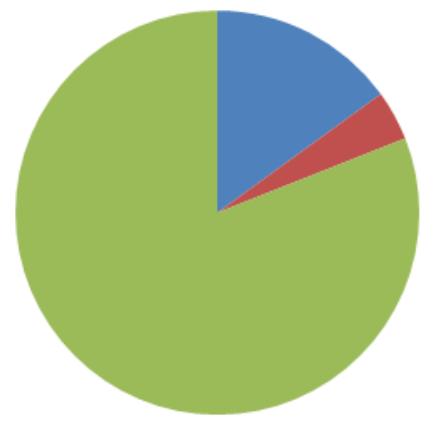

reciklirani asfalt (15\%)

asfaltno vezivo (4\%)

- agregat (81\%)

\section{Slika 5 - Sastav uobičajene vruće asfaltne smjese [15]}

lako naizgled čist materijal nakon ugradnje, proizvodnja asfalta, odnosno sastojaka asfalta, ima ozbiljne okolišne i zdravstvene utjecaje, među koje se ubrajaju korištenje neobnovljive nafte i agregata, potencijalno opasna isparavanja iz mješavina asfalta te doprinosi „urbanim toplinskih otocima“ zbog tamne boje asfalta.

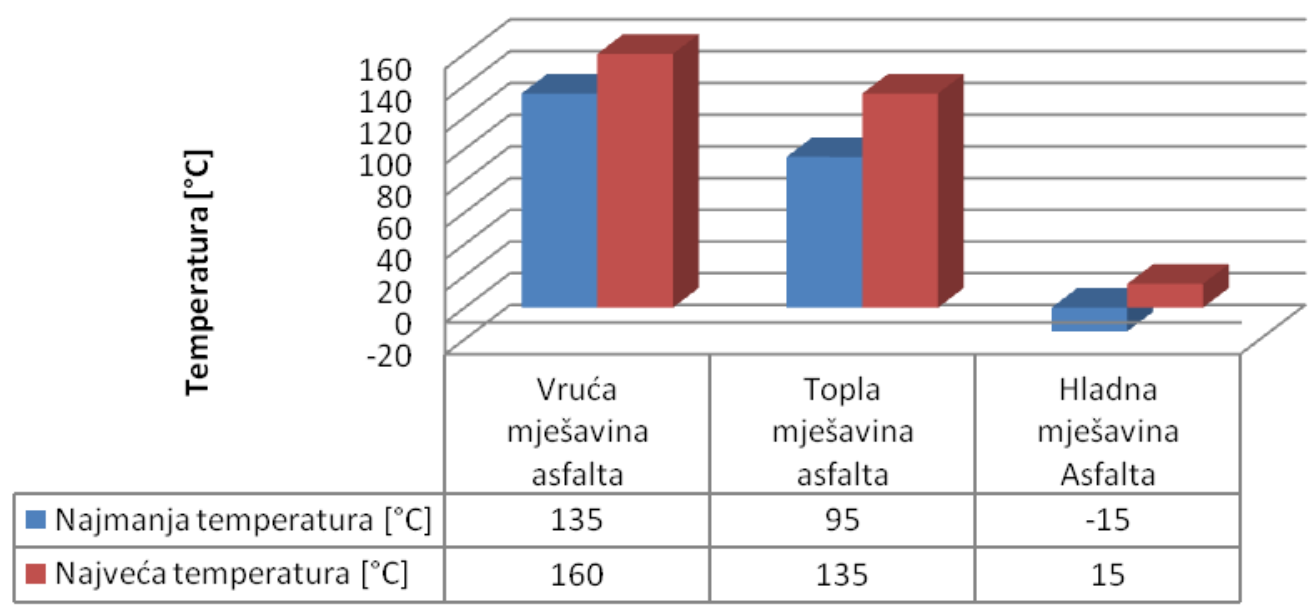

\section{Slika 6 - Temperaturni raspon pri nanošenju asfalta $[16,17]$}

Načini na koje se ovaj materijal može učiniti ekološki povoljnijim su smanjenje temperature miješanja i nanošenja, reciklirani sadržaj u vezivu te korištenje recikliranih agregata. Povoljni ekološki trend asfaltne industrije najviše je vidljiv u činjenici da uobičajena asfaltna mješavina često sadrži i postotak recikliranog asfaltnog zastora, što smanjuje korištenje prirodnih agregata za oko 15\% i asfaltnog veziva za oko 1\% [15].

\subsubsection{Smanjenje temperature mješavine asfalta}


Smanjenje temperature pri kojoj se asfalt miješa i nanosi može doprinijeti smanjenju nekih od negativnih ekoloških i zdravstvenih utjecaja tradicionalnog vruće miješanog asfalta. Moguće prednosti snižavanja temperature proizvodnje i nanošenja asfaltnih mješavina su sljedeće [16]: uštede energije, umanjena isparavanja, usporeno starenje asfaltnog veziva, umanjeno trošenje opreme.

Smanjujući temperaturu mješavina, smanjuju se isparavanja (Slika 7), otpuštanje stakleničkih plinova i potrošnja goriva za grijanje asfalta, bez štete po svojstva asfalta. Osim toga, uz uštedu energije povezuje se i ušteda novca, a za tržište je to vrlo bitna stavka. Tople mješavine asfalta, $s$ temperaturama manjim za $10^{\circ} \mathrm{C}$ do $40^{\circ} \mathrm{C}$, moguće su uz korištenje asfaltnih emulzija, pjenastih procesa ili dodataka koji povećavaju obradivost asfalta na nižim temperaturama. Istraživanjima [2] je potvrđeno kako se smanjenjem temperature mješavine $s$ prosječnih $150^{\circ} \mathrm{C}$ na $95^{\circ} \mathrm{C}$ i korištenjem asfaltne emulzije mogu postići uštede energije od čak $50 \%$.

Trenutačno postoje četiri procesa proizvodnje toplih mješavina asfalta, od kojih su neki zakonom zaštićeni[16]:

- Pjenasti proces - podrazumijeva ubrizgavanje hladne vode u toplo asfaltno vezivo, što izaziva pjenastu reakciju i smanjenje krutosti mješavine uz povećanu obradivost. Novostečene karakteristike omogućuju nanošenje asfalta pri manjim temperatura mješavine (oko $110^{\circ} \mathrm{C}$ ). Tehnika ubrizgavanja hladne vode ovisi o proizvođaču.

- Miješanje asfalta uz mineralne dodatke je postupak u kojemu se zeoliti, hidratizirani mikroporozni aluminoslilikati, u malim koncentracijama dodaju u mješavinu. Kao i pjenasti asfalt, ovakva mješavina ima povećanu obradivost, što omogućuje manje temperature nanošenja asfalta, od $120^{\circ} \mathrm{C}$ do $145^{\circ} \mathrm{C}$.

- Miješanje asfalta uz organske dodatke, parafine i spojeve estera, mijenja njegove karakteristike tako da snižava viskoznost uz istovremeno zadržavanje krutosti. Nanošenje je moguće izvršiti pri manjim temperaturama $-120^{\circ} \mathrm{C}$.

- Kemijski izmijenjeno vezivo ugrađeno u mješavinu dopušta nanošenje i zbijanje pri vrlo malim temperaturama, čak $60^{\circ} \mathrm{C}$. S obzirom na to da su ovakvi proizvodi zakonom zaštićeni, točni sastojci koji se primjenjuju u procesu proizvodnje nisu poznati - ovo djelomično otežava određivanje količina emisija, no one su manje od uobičajenog vruće miješanog asfalta [2].

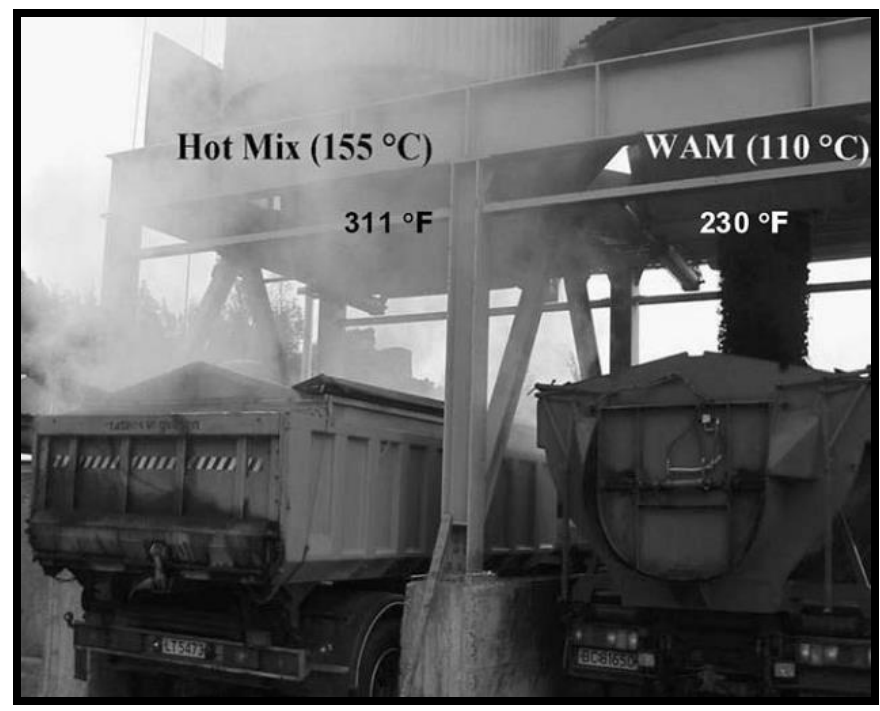

\section{Slika 7 - Usporedni utovar kamiona s vrućom mješavinom asfalta (lijevo) i toplom mješavinom asfalta} (desno) - isparavanja su vidno veća iz kamiona s vrućom mješavinom $[2,17]$

Hladna mješavina asfalta, u kojoj se koristi asfaltna emulzija pomiješana pri okolišnoj temperaturi, još je jedan od načina na koji je moguće uštedjeti gorivo i smanjiti ugljične emisije i isparavanja. Osnovna primjena hladnog miješanja jest popravak cesta i hladno in-situ recikliranje asfalta. Hladnom mješavinom se u pravilu ne rade novi asfaltni zastori - iznimke su gradilišta na velikim udaljenostima od tvornica vrućih mješavina. Većina hladnih mješavina radi se na samom gradilištu ili u transportnim in-situ tvornicama, no cijena potrebne pokretne opreme za miješanje je velika, tako da su hladne mješavine ograničene na manje projekte. Još jedno ograničenje 
ovakvih mješavina vezano je uz urbana područja, gdje često nema mjesta za opremu i skladištenje materijala, a i neke prometnice ne mogu se zatvoriti toliko dugo koliko to zahtijeva nanošenje i očvršćivanje hladne mješavine asfaltnog zastora.

\subsubsection{Korištenje recikliranih agregata}

Mnogi danas dostupni otpadni materijali mogu se koristiti kao agregat, mineralna ispuna, ili baza u asfaltnim primjenama, na taj način ostvarujući uštede prirodnih materijala i umanjujući negativne ekološke učinke rudarske i prerađivačke industrije takvih materijala. Osim recikliranog asfalta, koji se najčešće koristi kao reciklirani materijal u asfaltu, materijali koje je moguće koristiti u asfaltu su guma, šindra, zgura, staklo i beton (Tabela 4).

Osim ekoloških dobrobiti, korištenje recikliranih materijala u asfaltu može imati za posljedicu uštede novca, bilo kroz očito manju cijenu recikliranih materijala, koja je često samo cijena transporta, ili kroz izostanak naknada za odlaganje.

Tabela 4 - Reciklirani materijali prikladni za uporabu u asfaltnim kolnicima [18]

\begin{tabular}{|c|c|c|c|}
\hline Primjena & Reciklirani materijal & Primjena & Reciklirani materijal \\
\hline $\begin{array}{l}\text { Asfaltni zastor } \\
\text { Mineralno punilo }\end{array}$ & $\begin{array}{l}\text { Prašina iz asfaltnih tvornica } \\
\text { Pepeo kanalizacijskih taloga } \\
\text { Prašina iz cementnih peći } \\
\text { Prašina iz vapnenačkih peći } \\
\text { Ugljeni leteći pepeo } \\
\text { Zgura visokih peći } \\
\text { Ugljeni pepeo } \\
\text { Ugljena zgura } \\
\text { Ljevački pijesak } \\
\text { Otpad prerade minerala } \\
\text { Pepeo komunalnog otpada } \\
\text { Nemetalna zgura } \\
\text { Naftno kontaminirana tla } \\
\text { Reciklirani asfalt } \\
\text { Otpadna šindra } \\
\text { Otpadne gume } \\
\text { Čeličanska zgura } \\
\text { Otpadno staklo }\end{array}$ & Stabilizirajuća baza & $\begin{array}{l}\text { Zgura visokih peći } \\
\text { Ugljeni pepeo } \\
\text { Otpad od prerade minerala } \\
\text { Reciklirani beton } \\
\text { Nemetalna zgura } \\
\text { Komunalni otpad } \\
\text { Naftno kontaminirana tla } \\
\text { Čeličanska zgura } \\
\text { Otpadno staklo } \\
\text { Reciklirane gume } \\
\text { Ugljeni pepeo } \\
\text { Ugljena zgura } \\
\text { Reciklirani asfalt } \\
\text { Naftno kontaminirana tla }\end{array}$ \\
\hline
\end{tabular}

Kako je dostupnost recikliranih materijala za asfaltne mješavine vezana uz industrije određenih regija, najisplativije i ekološki najodgovornije je korištenje lokalno dostupnih materijala.

Naravno, korištenje recikliranih agregata ima i neka ograničenja, odnosno nedostatke. Ponekad nečistoće i nepoznati sastojci recikliranih materijala, koji su većinom nusprodukti drugih industrija, mogu umanjiti trajnost i čvrstoću kolnika. Ovakav nedostatak se ponajviše očituje i kroz trenutačno najzastupljeniji reciklirani materijal u asfaltnim mješavinama, reciklirani asfalt, za kojega se smatra da, zbog godina korištenja, sadrži nepoznata onečišćenja i/ili teške metale koji mogu utjecati na zdravlje ljudi te trajnost i kvalitetu konačnog proizvoda [2]. Osim toga, neki od recikliranih materijala su porozniji od prirodnih agregata, stoga treba upotrijebiti više asfaltnog veziva kako bi mješavina bila dostatne kvalitete, a to je suprotno od početne ideje o što manjem negativnom utjecaju na okoliš. S obzirom na to da je mnogo načina na koje je moguće umanjiti negativne učinke asfalta na prirodni okoliš, ključne strategije su ukratko prikazane u Tabela 5.

Tabela 5 - Kratki prikaz mjera za umanjenje negativnih ekoloških učinaka asfalta 


\section{Ključne strategije umanjenja negativnih učinaka asfalta}

- Ohrabriti izvođače da smanje temperature mješavina asfalta i primijene kontrole ograničavanja isparavanja.

- Koristiti asfaltna veziva koja sadrže što manje otapala i razrjeđivača.

- Projektirati kolnike sa što tanjim asfaltnim slojevima i debljim neasfaltnim stabilizirajućim slojevima, a u takvima koristiti reciklirane agregate gdje god je to moguće.
- Produljiti životni vijek zastora preventivnim održavanjem kao što su popravci i obnavljanje površinskog sloja.

- Zamijeniti dio agregata recikliranim materijalima kao što su reciklirani asfalt, guma, staklo, zgura, drobljeni beton, šindra i slični.

\subsection{Metali}

Metali kao građevinski proizvodi imaju mnoge prednosti. Ako se koriste i održavaju na ispravan način, mogu biti vrlo trajni s dužim životnim vijekom od drveta, betona ili plastike. Mnogi od njih imaju visok omjer nosivosti i vlastite težine, što omogućuje gradnju vitkih konstrukcija. Dostupni su u širokom spektru oblika, može ih se lijevati ili kovati, a takvi oblici omogućuju razne arhitektonske i konstrukcijske primjene.

Navedene prednosti potrebno je odvagnuti s nedostatcima, ozbiljnim ekološkim i zdravstvenim učincima koje ima rudarska i proizvođačka industrija. Ovi učinci značajno odstupaju, ovisno o vrsti metala, samog proizvoda, a i uporabe, ali svakako je moguće reći kako se pri proizvodnji metala koriste velike količine prirodnih izvora - volumen proizvedenih metala je tri do osam puta manji od potrebnog volumena sirovina u proizvodnji, što za posljedicu ima vrlo velike količine otpada. Otpad se oslobađa u zrak, vodu i tlo, gdje utječe na ekosustave i time na ljude.

Jedna od najviše „zelenih“ karakteristika metala jest mogućnost gotovo neizmjernog recikliranja. Korištenje otpada štedi značajne količine energije te umanjuje ostatke i onečišćenje u proizvodnji novih materijala - stoga je prerada metala vrlo razvijena i gospodarski snažna djelatnost. Upravo ova značajka, usklađena s naporima industrije na unaprjeđenju proizvodnog procesa (kritična faza životnog ciklusa metala), omogućuje pad emisija $\mathrm{CO}_{2}$ i time doprinosi održivoj gradnji (Slika 8). Osim toga, već spomenuta trajnost metalnih konstrukcija značajna je „zelena“ karakteristika.

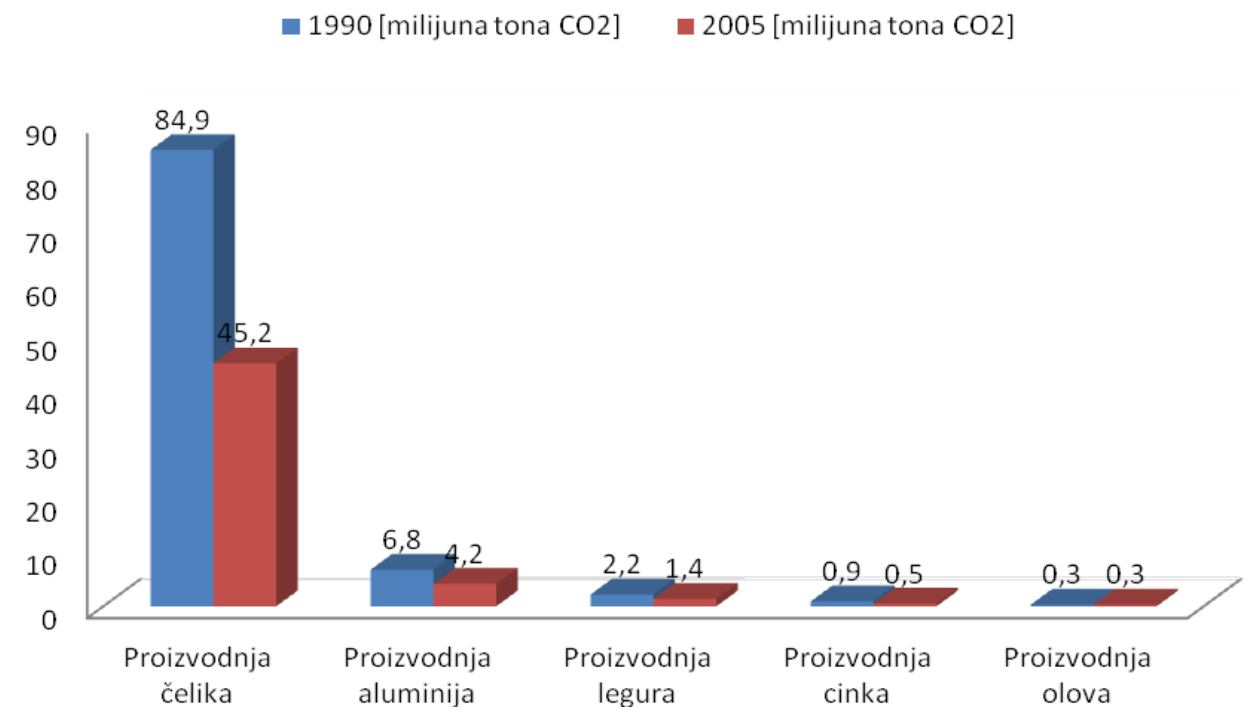

Slika 8 - Ukupne emisije $\mathrm{CO}_{2}$ pri proizvodnji metala (SAD) u milijunima tona [19]

\subsection{1 Čelik}


Čelik je najvažniji i najrasprostranjeniji metal na svijetu, s proizvodnjom od 1414 milijuna tona u godini [20](2010. godina), a uz to i ekološki najznačajniji ako se promatraju emisije (Slika 8). Trenutačno je najveći proizvođač ovog metala u svijetu Kina (Slika 9), u kojoj još nisu provedene mjere koje bi značajnije ograničile emisije ugljika, a i ostali vodeći proizvođači imaju značajan prostor za napredak u kontekstu umanjenja utjecaja na okoliš. Spomenuto umanjenje, odnosno prostor za ostvarenje najvećih pomaka jest faza proizvodnje. Naime, ako se promotri životni ciklus čelika (Slika 10), moguće je vidjeti kako je on gotovo idealan, zatvorena kružna petja, ali faza proizvodnje stvara značajna onečišćenja.

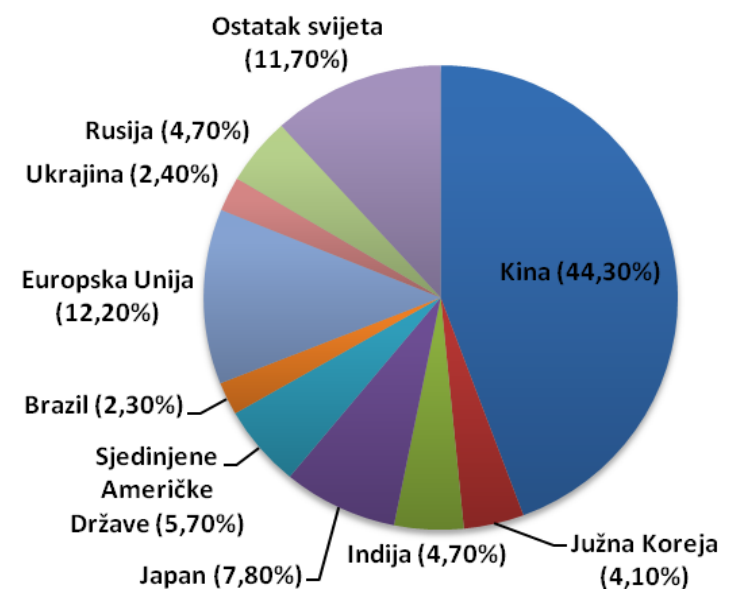

\section{Slika 9 - Udjeli u svjetskoj proizvodnji čelika, 2010. godine [20]}

Zahvaljujući svojim mehaničkim, kemijskim i metalurškim svojstvima, čelik je pronašao mnoštvo primjena, a njegova razumna cijena i trajnost su poslužili kao katalizator u prodiranju na tržište. Budući da je to industrijski proizvod, može se reći djelo ljudske ruke, moguće mu je dodavanjem određenih elemenata (mangan, magnezij, krom, vanadij i slični) mijenjati mehanička svojstva, što je dodatno povećalo njegovu uporabu. Koristi se u građevinarstvu, industriji alata, mehaničkih uređaja te automobilskoj industriji. $S$ obzirom na tako raširenu uporabu, industrija čelika je danas vrlo snažna, ostvaruje velike profite i ima vrlo važnu ulogu u globalnoj ekonomiji, a takve činjenice daju za pravo očekivati značajna ulaganja u osuvremenjivanje postrojenja i time ekološku prilagodbu.

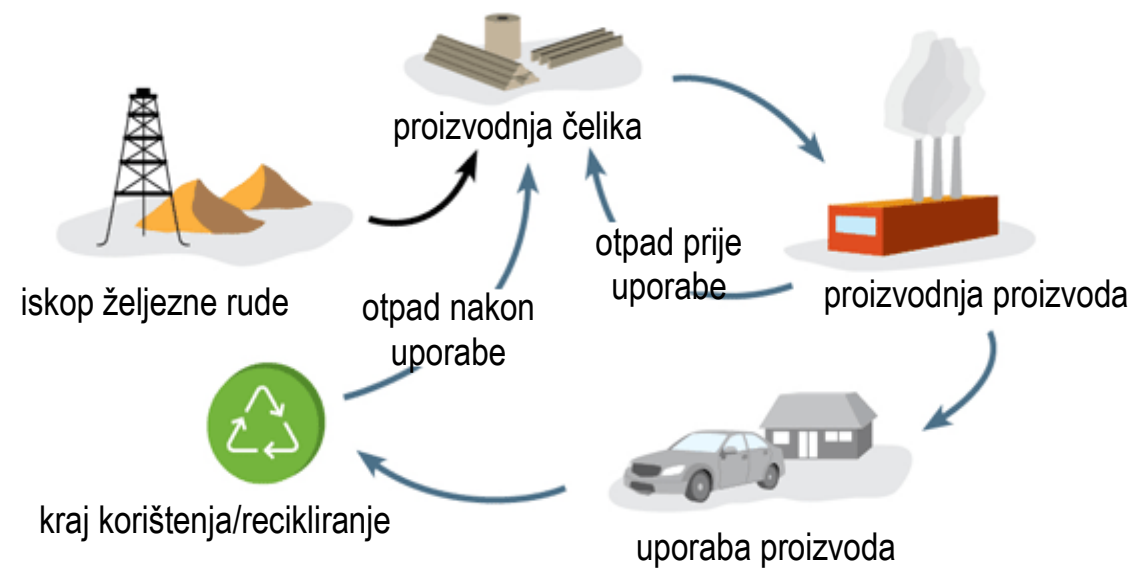

\section{Slika 10 - Životni ciklus čelika [20]}

Proizvodnja čelika je energetski vrlo intenzivan proces pri kojemu se troši mnogo fosilnog goriva te u atmosferu oslobađa velika količina $\mathrm{CO}_{2}$. Globalno gledajući, industrija čelika je odgovorna za 3-4\% [21] emisija stakleničkih plinova. Za svaku tonu proizvedenog čelika proizvede se i 1,9 [21] tona ugljičnog dioksida, 
prvenstveno kao posljedica izgaranja velikih količina ugljena. Upravo zbog toga industrija čelika se smatra glavnom metom Kyoto protokola, iako je potrošnja energije po toni čelika prepolovljena od 1975. godine.

Peći u kojima se vrši obrada ruda za daljnji proces proizvodnje čelika uzrokuju najveći dio onečišćenja u tijeku faze proizvodnje. Danas se u svijetu koriste dvije vrste peći, visoke i elektrolučne.

Ako se usporede emisije $\mathrm{CO}_{2}$ pri uporabi pojedinih peći (Slika 11), moguće je primijetiti kako se visoke i elektrolučne peći značajno razlikuju. Proizvodnja čelika u visokim pećima, zbog iskorištavanja velikih količina ugljena pri taljenju rude, ima za posljedicu četiri puta veću emisiju $\mathrm{CO}_{2}$ od proizvodnje čelika u elektrolučnim pećima (radi se o mješavini sa $100 \%$ udjela otpadnog čelika). Kada je u mješavini udio čeličnog otpada $70 \%$ i rude $30 \%$, proizvodnjom u elektrolučnim pećima moguće je smanjiti količinu $\mathrm{CO}_{2}$ za oko 780 kilograma po toni tekućeg čelika [21].

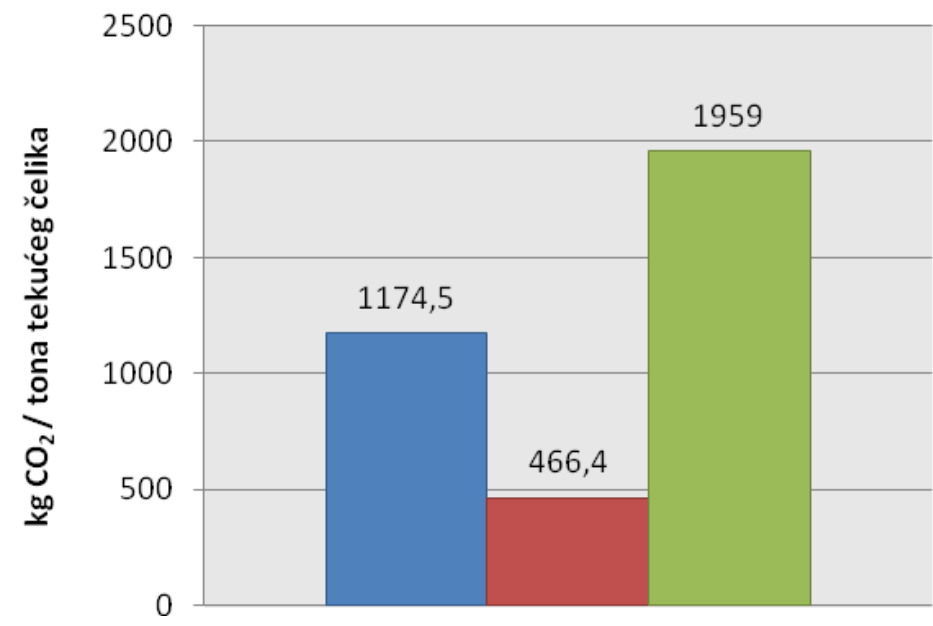

\author{
Elektrolučne peći $(70 \%$ \\ otpada; $30 \%$ rude) \\ EElektrolučne peći $(100 \%$ \\ recikliranje otpada)
}

$\square$ Visoke peći

\section{Slika 11 - Usporedba emisije $\mathrm{CO}_{2}$, ovisno o vrsti peći za proizvodnju čelika [21]}

Kako je emisija $\mathrm{CO}_{2}$ proporcionalna potrošnji energije, moguće je zaključiti da je proizvodnja novog čelika iz rude energetski zahtjevnija od proizvodnje novog čelika od recikliranog materijala. Drugim riječima, iz prikazanih podataka vidljivo je da porastom udjela rude u mješavini za proizvodnju novog čelika raste razina potrošnje energije. Naime, reciklirani čelik u mješavini za proizvodnju daje otprilike jednaku količinu novog čelika, a ruda se preradom rastvara dajući pritom nusprodukte i znatno manje čelika od ulazne mase rude. Ako se izuzme sastav mješavine, elektrolučna peć zahtijeva manje energije pri proizvodnji jer je zapravo suvremena inačica peći za proizvodnju čelika (Tabela 6). Osim same peći, energetska učinkovitost čeličana ovisi o vrsti rude i ugljena koji se koristi te stupnju modernizacije cijelog postrojenja.

Tabela 6 - Usporedba potrošnje energije u proizvodnji čelika (po toni proizvedenog čelika), ovisno o vrsti peći [21]

\begin{tabular}{cc}
\hline Vrsta proizvodnje čelika & Potrošnja energije [GJ/t] \\
\hline Visoka peć & $19,8-31,2$ \\
\hline Elektrolučna peć & $9,1-12,5$ \\
\hline
\end{tabular}

Osim emisija ugljika te neizravnog onečišćavanja kroz velike potrošnje energije, industrija čelika je veliki onečišćivač vode, no taj nedostatak je u većini zemalja uklonjen zakonskim odredbama koje zahtijevaju mjere filtriranja i pročišćavanja otpadnih voda.

U gotovo svim državama svijeta razvijena je djelatnost recikliranja čelika. Naime, čelik je jedini materijal koji se može u potpunosti reciklirati, a upravo zato je često na prvim mjestima kada je riječ o količinama recikliranog materijala. Tijekom zadnjih desetljeća, razvojem svijesti o recikliranju, mogućnostima recikliranja te postupnim informiranjem stanovništva, otpadni čelik postao je osnovica proizvodnje novog čelika, a upravo tomu teži održiva 
gradnja. Naime, po principu koji je prikazan u ranijem tekstu, recikliranjem se postigao pad emisija stakleničkih plinova (Slika 8) koji je potrebno zadržati tako da se postotak recikliranog čelika povećava, uz stalna ulaganja u postrojenja za proizvodnju (Slika 12).

Najveći „Zeleni adut“, recikliranje, industrija čelika iskorištava najbolje upravo preko građevinskog, odnosno konstrukcijskog čelika, tako da je trenutačna razina recikliranja takvog čelika (SAD) oko 98\% [22]. Ovaj podatak je zaista prava potvrda održive gradnje i mogućnosti recikliranja, a kao takvog ga prepoznaju i sustavi certificiranja pomoću kojih ovaj pothvat prepoznaje i šira javnost.

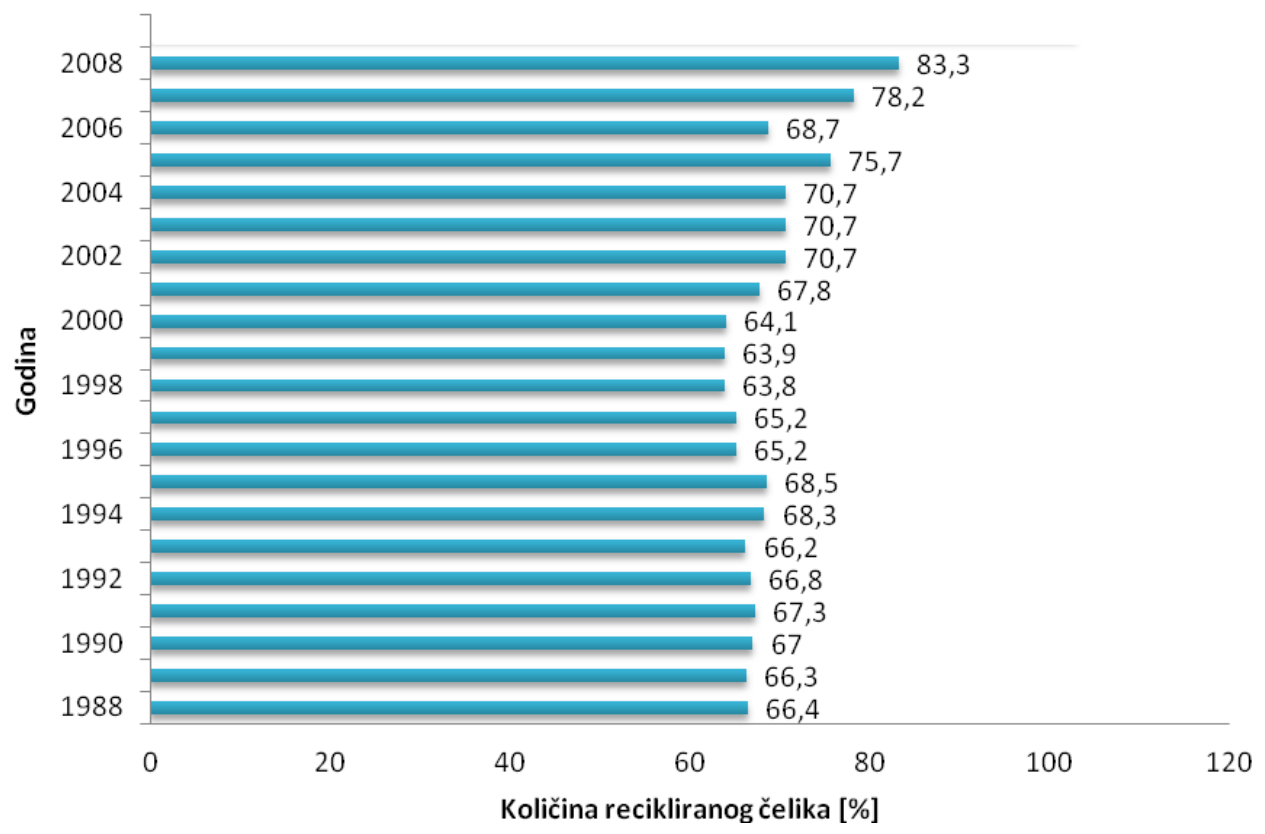

Slika 12 - Stopa ukupno recikliranog čelika u svijetu (1988 - 2009) [23]

Reciklaža i utjecaj na proizvodnu fazu čelika jesu nužnosti koje omogućuju značajna smanjenja utjecaja na prirodni okoliš, ali uz te procese potrebno je što bolje iskoristiti povoljna svojstva čelika kao što su trajnost i povoljan odnos nosivosti i vlastite težine, kako bi se poželjni ekološki trendovi potvrdili. Trajnost čelika je potrebno osigurati pravilnim održavanjem i preventivnim mjerama koje uključuju nanošenje antikorozivne zaštite, bolje projektiranje detalja spojeva te kontekstno projektiranje - projektiranje prilagođeno uvjetima u kojima se nalazi konstrukcija.

Visoke čvrstoće čelika daju projektantu mogućnost oblikovanja vitkih, manjih i inteligentnijih konstrukcija, što je naglašeno kroz povoljne parcijalne koeficijente [24] u odnosu na ostale materijale (Tabela 7). Osim toga, duktilnost čelika moguće je iskoristiti u trusnim područjima za gradnju vitkih konstrukcija. Naime, materijali koji su krući teže podnose dinamička opterećenja te je nedostatak duktilnosti nužno kompenzirati znatno većim utroškom materijala.

Tabela 7 - Prikaz parcijalnih faktora za beton, konstrukcijski čelik i betonski čelik [24, 25]

\begin{tabular}{lll}
\hline \multicolumn{2}{l}{ Parcijalni faktori za materijal $\left(\gamma_{M}\right)$} & \\
\hline \hline Beton $\left(\gamma_{c}\right)$ & Konstrukcijski čelik $\left(\gamma_{M}\right)$ & Betonski čelik $\left(\gamma_{\mathrm{V}}\right)$ \\
\hline 1,50 & 1,00 & 1,15 \\
\hline
\end{tabular}

Kako bi se osigurala održivost, pri projektiranju čelične konstrukcije arhitekti i građevinski inženjeri moraju poznavati mehanizam degradacije, bilo sa stanovišta projektiranja i izvođenja, bilo sa stanovišta predviđanja životnog vijeka materijala.

\subsubsection{Aluminij}


Aluminij je drugi po redu metal po proizvodnji i ekološkim utjecajima (Slika 8). Uporaba mu je raširena u industriji graditeljstva (pokrivanje fasada i krovova, oplate za beton, stolarija, konstrukcijski elementi), automobila i ambalažnoj industriji (aluminijske konzerve, folije za hranu itd.). Široku prepoznatljivost i sve veću uporabu duguje svojim povoljnim antikorozivnim svojstvima, čvrstoći, maloj gustoći i duktilnosti (Slika 13).

lako je aluminij metal koji je na zemlji najviše dostupan, gotovo nikada ne dolazi u elementarnom stanju pa je crpljenje ruda (boksit) energetski vrlo zahtjevan i ekološki nepovoljan postupak. Međutim, kao i čelik, aluminij je ekološki prihvatljiv zbog mogućnosti recikliranja, a ta mogućnost je ovdje još povoljnija zbog njegove manje temperature tališta, tako da se recikliranje obavlja s relativno malo energije. Naime, pri postupku dobivanja novog aluminija od recikliranog materijala koristi se samo oko 5\% [26] energije i proizvodi samo $5 \% \mathrm{CO}_{2}$ u usporedbi s proizvodnjom aluminija iz boksita.

Zbog energetski intenzivnog procesa proizvodnje, slično kao i kod čelika, nužno je uvesti moderne postupke prerade ruda i otpadnog aluminija, a električnu energiju potrebnu za takve procese treba proizvoditi na ekološki čist način (geotermalne elektrane, solarne elektrane, hidroelektrane).

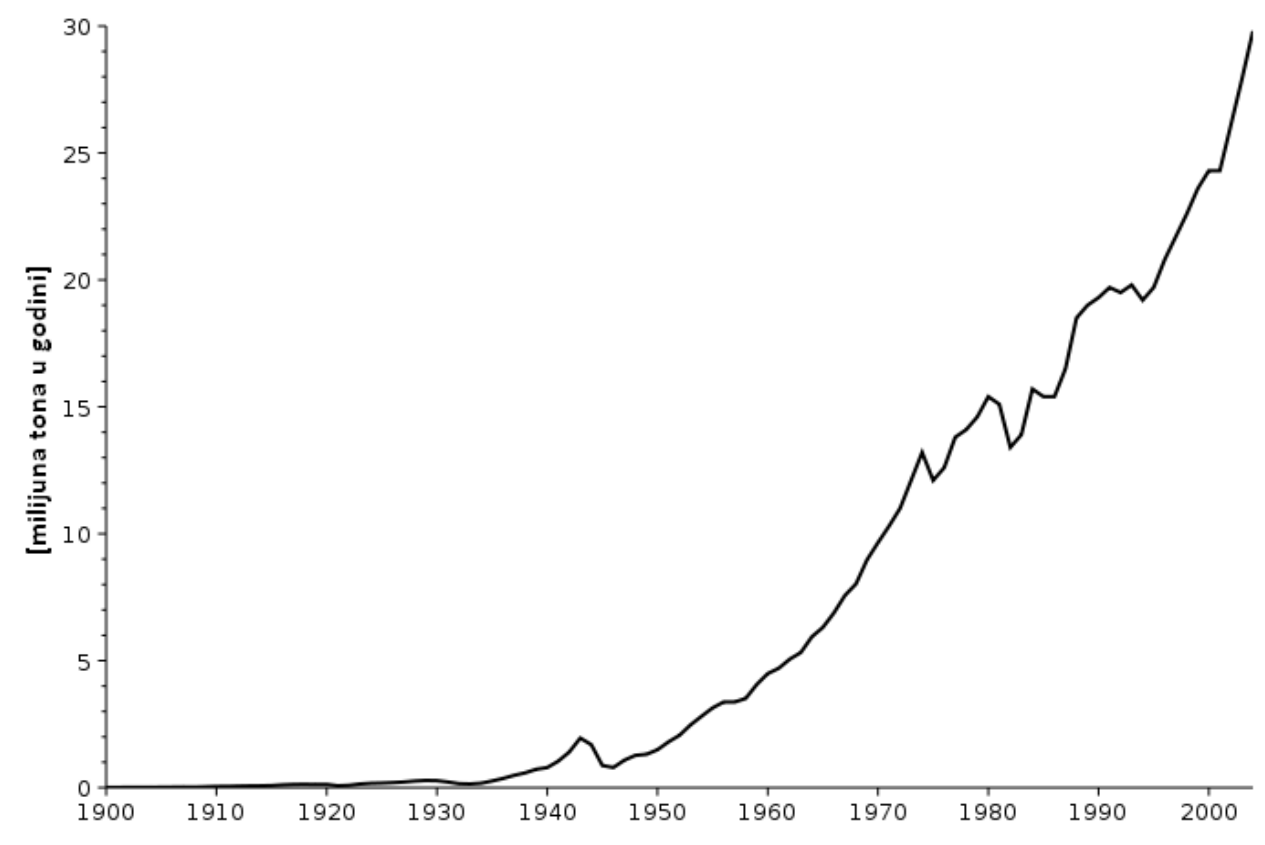

Slika 13 - Svjetska proizvodnja aluminija u milijunima tona po godini [26]

„International Aluminium Institute“ je 2003. godine objavio kako više od 75\% svjetskih proizvođača aluminija provodi mjere prilagodbe proizvodnje kako bi se umanjili štetni učinci po okoliš. Ovakav postotak je zasigurno potvrda tržišne prihvatljivosti materijala pri proizvodnji kojih postoji nakana umanjenja utjecaja na prirodu.

Ostale mogućnosti umanjenja ekoloških utjecaja aluminija, u kontekstu građevinarstva, moguće je ostvariti po sličnim principima koji su izloženi u potpoglavlju 3.3.1 Čelik.

\subsection{Stanje u Hrvatskoj}

Kroz dosada obrađena poglavlja prikazane su mogućnosti „zelene“ gradnje i razne pogodnosti uporabe određenih zamjena konvencionalnih materijala, a kroz te pogodnosti i njihove možebitne i stvarne tržišne 
vrijednosti. Cilj ovog poglavlja je prikazati mogućnost uporabe navedenih zamjenskih materijala u Hrvatskoj, ne ulazeći u zakonodavni okvir koji je tema drugoga dijela ovoga članka.

Kao što je navedeno ranije u tekstu, tržišna prihvatjjivost materijala s malom razinom ugljika uvelike je ovisna o lokaciji dostupnih alternativnih sirovina. Naime, lokalna dostupnost alternativnog izvora čini proizvod jeftinijim i ekološki povoljnijim, a osim toga, korištenje takvih materijala, koji su kao otpad problem određene lokalne zajednice, kako bi se napravio novi proizvod, omogućuje zajednici izravan uvid u ekološki proces i predstavlja poticaj za bolju prihvaćenost proizvoda.

Hrvatska treba recikliranjem uključiti građevinski i ostali primjenjivi otpad u proizvodni proces materijala, treba pokušati iskoristiti sve ranije u članku prikazane mogućnosti uporabe otpada. lako trenutačno ne postoji kvalitetna evidencija izvora i količina građevinskog otpada, a tako niti ostalog, postoje zasebna istraživanja pomoću kojih je moguće utvrditi potencijale za ekološku gradnju alternativnim inačicama konvencionalnih materijala.

Već se iz geografskih specifičnosti Republike Hrvatske da naslutiti u kojem području prevladava koji otpadni građevinski materijal - tako u Dalmaciji i Primorju imamo kamen, u sjeverozapadnom dijelu beton i opeku, a u istočnom također opeku, odnosno miješani otpad. Na temelju podataka prikupljenih u okviru projekta CONWAS (LIFE05 TCY/CRO/000114 CONWAS - Razvoj održivog sustava upravljanja građevinskim otpadom u Republici Hrvatskoj), podataka Agencije za zaštitu okoliša i podataka Državnog zavoda za statistiku, procijenjeno je kako se godišnje odlaže 2345273 [14, 27] tone građevinskog otpada, kojega u najvećem dijelu čini beton (Slika 14).

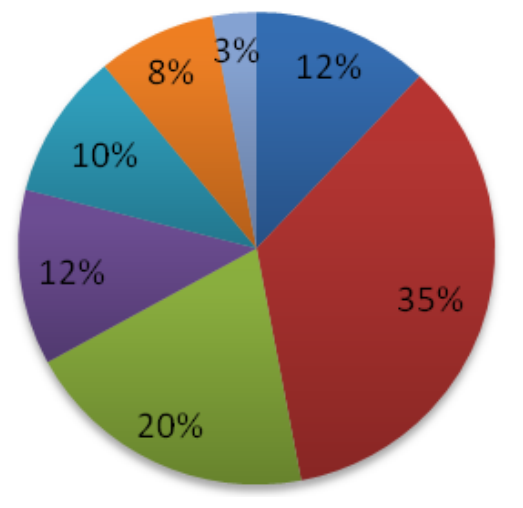

\author{
- Opeka \\ Beton \\ Drvo \\ - Zemljani materijal \\ - Umjetni materijal \\ - Čelik \\ Ostalo
}

\title{
Slika 14 - Sastav građevinskog otpada u Hrvatskoj, nastalog pri rušenju stambenih zgrada [14]
}

U Hrvatskoj se 2007. godine recikliralo samo 5\% [28] građevinskog otpada, a 2008. godine stupanj recikliranja građevinskog otpada nije prelazio 7\% [14], sa stupnjem izdvajanja sekundarnih sirovina oko 11\% [14]. U pojedinim jedinicama lokalne samouprave više od $80 \%$ [14] otpada odloženog na divlja odlagališta čini građevinski otpad. Osim otpada nastalog rušenjem građevina, postoji otpad koji je nastao u tijeku proizvodnih procesa građevinskih elemenata. Primjerice, u opekarskoj industriji u procesu proizvodnje i transporta unutar tvornice može doći do oštećenja proizvoda koji postaju neupotrebljivi za prodaju. Sve ove činjenice daju naslutiti kako postoji još mnogo prostora za djelatnost reciklaže građevinskog otpada u Hrvatskoj.

Već sastav otpada, stupnjevi reciklaže i količina ukupnog građevinskog otpada daju naslutiti kako postoji realni potencijal za uporabu takvih materijala pri proizvodnji novih građevinskih materijala s malim udjelom ugljika koji bi, zbog navedenih razloga, bili iznimno konkurentni na tržištu. Osim što se ovakav zaključak može izvući iz već tako ograničenog broja podataka, provedena istraživanja [14, 29-31] na razini Hrvatske, kroz ocjenu određenih materijala iz sporednih izvora dostupnih u većim količinama (Tabela 8), predstavljaju smjernicu daljnjeg rada po tom pitanju.

Tabela 8 - Agregati iz sporednih izvora, crvenom označeni oni dostupni u većim količinama [29]

\begin{tabular}{|l|l|c|l|}
\hline \hline Oznaka & Podrijetlo/izvor & Podoznaka & Materijal \\
\hline A & Građevinarstvo i recikliranje & $\mathrm{A} 1$ & Obnovljeni (reciklirani) asfalt \\
\hline
\end{tabular}




\begin{tabular}{|c|c|c|c|}
\hline & \multirow[t]{3}{*}{ materijala dobivenih rušenjem } & A2 & Drobljeni beton \\
\hline & & A3 & Drobljena opeka i ziđe \\
\hline & & A4 & Mješavina A1, A2 i A3 \\
\hline \multirow{2}{*}{ B } & \multirow{2}{*}{$\begin{array}{l}\text { Spaljivanje krutog komunalnog } \\
\text { otpada }\end{array}$} & B1 & Nataloženi pepeo (izuzev letećeg pepela) \\
\hline & & B2 & Leteći pepeo \\
\hline \multirow{5}{*}{ C } & \multirow{5}{*}{ Proizvodnja energije na bazi ugljena } & $\mathrm{C} 1$ & Leteći pepeo kao produkt izgaranja ugljena \\
\hline & & $\mathrm{C} 2$ & Leteći pepeo kao produkt izgaranja tekuće podloge \\
\hline & & $\mathrm{C} 3$ & Zgura iz kotlova \\
\hline & & $\mathrm{C} 4$ & Nataloženi pepeo kao produkt izgaranja ugljena \\
\hline & & C5 & $\begin{array}{l}\text { Nataloženi pepeo kao produkt izgaranja tekuće } \\
\text { podloge }\end{array}$ \\
\hline \multirow{5}{*}{ D } & \multirow{5}{*}{ Crna metalurgija } & D1 & Čelična zgura \\
\hline & & $\mathrm{D} 2$ & Kristalizirana zgura iz visokih peći (zračno hlađena) \\
\hline & & D3 & Glazirana zgura iz visokih peći \\
\hline & & D4 & Zgura iz elektrolučnih peći \\
\hline & & D5 & Zgura od nehrđajućeg čelika \\
\hline \multirow{4}{*}{$\mathbf{E}$} & \multirow{4}{*}{ Obojena metalurgija } & $\mathrm{E} 1$ & Zgura od bakra \\
\hline & & E2 & Zgura od molibdena \\
\hline & & E3 & Zgura od cinka \\
\hline & & E4 & Zgura od fosfora \\
\hline \multirow{2}{*}{$\mathbf{F}$} & \multirow{2}{*}{ Lijevanje metala(ljevaonice) } & $\mathrm{F} 1$ & Pijesak dobiven lijevanjem \\
\hline & & F2 & Zgura dobivena lijevanjem u kupolastim pećima \\
\hline \multirow{4}{*}{ G } & \multirow{4}{*}{ Rudarstvo I kamenolomi } & G1 & Šejl od crvenog ugljena \\
\hline & & G2 & Otpad dobiven vađenjem kamenog ugljena \\
\hline & & G3 & $\begin{array}{l}\text { Prethodno selektirani neseparirani agregat iz } \\
\text { kamenoloma }\end{array}$ \\
\hline & & G4 & Šejl od otpadne nafte \\
\hline \multirow{2}{*}{$\mathrm{H}$} & \multirow{2}{*}{$\begin{array}{l}\text { Iskop (bageriranje pod vodom) u } \\
\text { sklopu održavanja }\end{array}$} & $\mathrm{H} 1$ & Otpadni pijesak \\
\hline & & $\mathrm{H} 2$ & Otpadna glina \\
\hline \multirow{4}{*}{ I } & \multirow{4}{*}{ Razno } & 11 & Pepeo od papira \\
\hline & & 12 & Pepeo dobiven spaljivanjem komunalnog otpada \\
\hline & & 13 & Pepeo od biomase \\
\hline & & 14 & Drobljeno staklo \\
\hline
\end{tabular}

\section{Zaključak}

Kroz članak su prikazane potvrde tržišta o prihvaćanju zelenih materijala kroz povećani broj istraživanja i ponude zamjenskih materijala konvencionalnim, ekološki štetnim materijalima, a uz to i moguće strategije smanjenja negativnih učinaka kroz projektiranje, koje se već primjenjuju u svijetu. Osim toga, prikazano je i kako su takvi materijali često jeftiniji, trajniji ili jednostavno bolji od svojih inačica, a nedostatci povezani s njima lako premostivi. Lokalna dostupnost materijala za proizvodnju inačica konvencionalnim materijalima, koja postoji u Hrvatskoj, može poslužiti samo kao dodatna povoljnost.

Zasigurno postoji još mnogo prostora za napredak ovakvih materijala u kontekstu tržišnog udjela, ali već sada se može reći kako postoji dovoljan interes i potreba za takvim materijalima te da imaju sigurnu budućnost. 
Svakako treba naglasiti da uporaba ekološki i energetski prihvatljivih materijala ne bi smjela ugroziti trajnost konstrukcija.

U konačnici, sve što čovječanstvo mora prihvatiti, a time će se i ovakvi materijali učiniti jedinim izborom, jest da nije moguće stanje privremenih, labilnih ravnoteža u svijetu, kakvo danas vrijedi, već je nužno uspostaviti stabilnu, dugoročnu ravnotežu odnosa između čovjeka i prirode, od koje je čovjek kao njezin integralni dio zastranio.

\section{Zahvala}

Ovaj članak predstavlja dio rada „Tržišna prihvatjivost građevinskog materijala s niskim udjelom ugljika" $s$ kojim su autori sudjelovali na projektu Case Study Competition 2011 u okviru poslovnog slučaja poduzeća Holcim (http://www.gfos.hr/portal/index.php/novosti/1441-case-study-competition-2011.html). Ovim putem autori se zahvaljuju tvrtki Holcim i udruzi e-Student zbog kojih je rad i nastao, te Društvu građevinskih inženjera Osijek na financijskoj potpori. Osim toga, autori se zahvaljuju doc.dr.sc. Zlati Dolaček-Alduk na potpori, korisnim savjetima i literaturi tijekom pisanja rada, te dr.sc. Krunoslavu Minažeku i Ivani Barišić na korisnim savjetima i literaturi.

\section{Literatura}

[1] Yudelson, J., Green Building A to Z, 2007, Gabriola Island, Canada: New Society Publishers.

[2] Calkins, M., Materials for Sustainable Sites, 2009, Hoboken, New Jersey, USA: John Wiley \& Sons, Inc.

[3] Hamond, G.; Jones, C., Inventory of Carbon and Energy, 2008, University of Bath: Bath.

[4] Athena Sustainable Materials Institute, A Life Cycle Perspective on Concrete and Asphalt Roadways: Embodied Primary Energy And Global Warming Potential, 2006, Athena Sustainable Materials Institute: Merrickville.

[5] Mehta, P.K., Reducing the Environmental Impact of Concrete. Concrete International, 2001: p. 61-66.

[6] Crouch, K.; Hewitt, R.; Byard, B., High Volume Fly Ash Concrete, in World of Coal Ash (WOCA), 2007, University of Kentucky: Covington, USA. p. 1-14.

[7] Humphreys, K.; Mahasenan, M., Substudy 8:Climate Change - Toward a Sustainable Cement Industry, 2002, World Business Council for Sustainable Development.

[8] Mehta, P.K., The role of fly ash in sustainable development, in Concrete, Fly Ash and the Environment Proceedings, 1998: San Francisco, USA. p. 13-25.

[9] Beslać, J.; Bjegović, D.; Rosković, R., Inovativni materijali i tehnologije u građenju i održavanju betonskih konstrukcija. Građevinar, 2005. 57(4): p. 247-255.

[10] NAHB Research Center's ToolBase.org. Mrežna stranica pregledana 15.04.2011.; http://www.toolbase.org.

[11] Sonoco Construction Products. Mrežna stranica pregledana 10.04.2011; http://www.sonotube.com.

[12] Ignjatić, G.; Netinger, I., Mogućnost primjene alkalijski aktivirane zgure kao veziva u mortu. e-GFOS, 2010. 1(1): p. 115-123.

[13] Taylor, C.P.; Kosmatka, H.S.; Voigt, F.G., Integrated Materials and Construction Practices for Concrete Pavement: A State-of-the-Practice Manual, 2006, Federal Highway Administration Office of Pavement Technology: Washington.

[14] Kesegić, I.; Bjegović, D.; Netinger, I., Upotreba reciklirane opeke kao agregata za beton. Građevinar, 2008. 61(1): p. 15-22.

[15] Lippiatt, C.B., BEES 4.0 Building for Environmental and Economic Sustainability Technical Manual and User Guide, 2007, National Institute of Standards and Technology: Gaithersburg.

[16] Newcomb, D., Warm Mix: The Wave of the Future? . Hot Mix Asphalt Technology, 2005: p. 33-36.

[17] National Asphalt Pavement Association (NAPA). Mrežna stranica pregledana 12.04.2011.; http://www.hotmix.org/.

[18] Recycled Materials Resource Center. Mrežna stranica pregledana 08.04.2011; http://www.rmrc.unh.edu/. 
[19] U.S. Environmental Protection Agency. Mrežna stranica pregledama 12.04.2011; http://www.epa.gov/climatechange/emissions/downloads/US_GHG_Inv_Annexes_1990-2005.pdf.

[20] Worldsteel association. Mrežna stranica pregledana 11.04.2011; http://www.worldsteel.org/?action=storypages\&id=370.

[21] Losowska, M., Embodied energy counting of sustainable heat, power and steel processes, 2011, Akureyri, Iceland: RES The School for Renewable Energy Scinece.

[22] American Institute of Steel Construction. Mrežna stranica pregledana 01.04.2011; http://www.aisc.org/content.aspx?id=3788.

[23] Steel Recycling Institute. Mrežna stranica pregledana 20.04.2011; http://www.recyclesteel.org/en/Recycling\%20Resources/ /media/Files/SRI/Media\%20Center/RATESHEET09sm.ashx.

[24] European Committee for Standardization (CEN), EN 1993-1-1, Eurocode 3: Design of steel structures Part 1-1: General rules, 2005, Brussels, Belgium: CEN.

[25] European Committee for Standardization (CEN), EN 1992-1-1, Eurocode 2: Design of concrete structures Part 1-1: General rules and rules for buildings, 2004, Brussels, Belgium: CEN.

[26] Wikipedia. Mrežna stranica pregledana 08.04.2011; http://en.wikipedia.org.

[27] Građevinski fakultet u Zagrebu; Institut Građevinarstva Hrvatske; Eko-flor Plus, LIFE05 TCY/CRO/000114 CONWAS - Razvoj održivog sustava upravljanja građevinskim otpadom u Republici Hrvatskoj, 2007, Građevinski fakultet u Zagrebu: Zagreb, Hrvatska.

[28] Poslovni dnevnik. Reciklira se samo pet posto građevnog otpada. Mrežna stranica pregledana 13.04.2011; http://www.poslovni.hr/vijesti/reciklira-se-samo-pet-posto-gradevnog-otpada-43006.aspx.

[29] Netinger, I., Predgotovljeni armiranobetonski elementi povećane požarne otpornosti, 2010, Sveučilište J. J. Strossmayera u Osijeku: Osijek.

[30] Netinger, I.; Rukavina, J.M.; Bjegović, D., Mogućnost primjene domaće zgure kao agregata u betonu. Građevinar, 2010. 62(1): p. 35-43.

[31] Netinger, I., et al., Primjena zgure iz čeličana kao agregata u betonu. Građevinar, 2011. 63(2): p. 169-175. 